\title{
SITE SUITABILITY ANALYSIS FOR COMMUNITY-BASED TROPICAL SEA CUCUMBER HOLOTHURIA SCABRA GROW-OUT IN NORTH SULAWESI WATERS
}

\author{
Marenda Pandu Rizqi and Supono* \\ Loka Konservasi Biota Laut. Research Center for Oceanography, \\ Indonesian Institute of Sciences (LIPI). Bitung, Indonesia. \\ *Correspondence author: <supono@lipi.go.id>
}

Received: February 2018

Accepted: January 2019

\begin{abstract}
North Sulawesi, a region that has experienced a decreasing population of commercial sea cucumbers in Indonesia, has recently been designated an aquaculture development area. Recent developments of sea cucumber Holothuria scabra hatchery technology have successfully enabled the small-scale enterprise to produce hatcheryreared sandfish for restocking purposes. However, the grow-out phase requires considerable resources including ex-situ grow-out sites, labor, and distribution. This study aims to investigate the suitability of some potential grow-out sites for juvenile $H$. scabra in North Sulawesi waters. Three traditional sea cucumber fishing grounds in coastal areas of North Minahasa regency in North Sulawesi, i.e., Tanjung Merah, Tasikoki and Makalisung, were examined to determine their suitability as a grow-out site. Several criteria encompassing bioecological (native sea cucumber population, seagrass bed population, competitor/predator), environmental (substrate, protection to weather, water quality, tidal cycle), and technical/support (access, safety, labor) were assessed in each site. Site suitability analysis using a multi-criteria decision-making tool, Analytical Hierarchy Process (AHP), shows that Tasikoki has the highest suitability score (48.94\%) followed by Tanjung Merah (27.18\%) and Makalisung (23.88\%). Tasikoki scores higher than the two other sites in 7 out of 11 sub-criteria, including native sandfish population, seagrass species, substrate, weather protection, safety, and community support. Our finding suggests that Tasikoki is bioecologically, environmentally, and technically the best potential site to be developed for $H$. scabra juvenile grow-out.
\end{abstract}

Keywords: Holothuria scabra, aquaculture, site suitability, North Sulawesi, analytical hierarchy process.

\section{INTRODUCTION}

Indonesian government has targeted an increased production of the sea cucumber fisheries sector from both capture and aquaculture fisheries. In total, 174.600 hectares of aquaculture development areas have been designed for sea cucumber aquaculture (DGA, 2015). This strategic plan aims to address overexploitation of wild sea cucumber population. It was recorded that sea cucumber production from capture fisheries in Indonesia has increased since the last decade, approaching 900 tons in average, representing all fisheries management areas (FMA) in Indonesia (DGCF, 2015). The average production growth based on recorded data from 11 established FMAs was about 7\% (DGCF, 2015).

North Sulawesi (seeFigure 1), located in FMA716 , experienced average increasing production of $4 \%$ with the total production nearly at 157 tons in 2014 (DGCF, 2015). The increasing pressure of capture fisheries has caused decreasing natural populations of sea cucumber based on time series data. Lane and Limbong (2013) reported that 


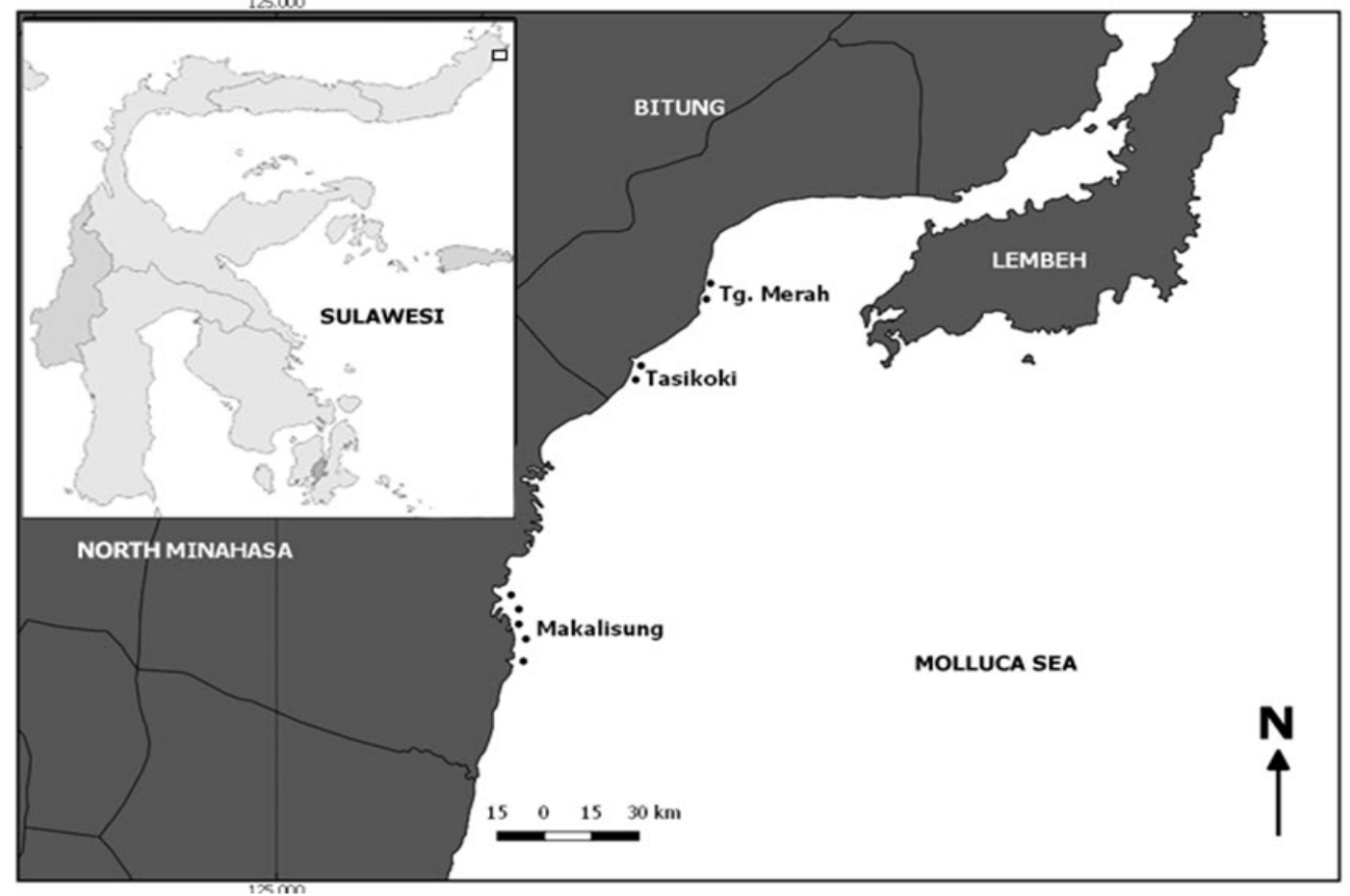

Figure 1. Map of the sampling sites.

over 17 years of observation, the cumulative number of high-value species was consistent, but their abundances were low.

There are no recently established statistics for sea cucumber fishery in North Sulawesi and adjacent waters. However, increasing harvesting pressure on sea cucumbers was reported in Makassar, South Sulawesi. Total export of over 15,000 tons of sea cucumber, with an average annual export of 600 tons was reported from this area from 1975 to 2009 (Máñez and Ferse, 2010). Similarly, a decreasing population of economically important sea cucumbers was evident through an ecological survey in North Sulawesi (Lane, 1999). This is consistent with some areas in North Sulawesi waters (Kema, Makalisung, Lilang, and Mangket) where sea cucumbers are heavily and frequently exploited by locals, particularly during low tide (Supono, unpublished data). Some fishermen also harvested high-value sea cucumber during the night using compressor dive method. In Kema waters, the exploitation has currently targeted low-value sea cucumber such as Holothuria atra (Supono, 2014). High intensity of sea cucumber harvesting was reported in Bunaken, North Sulawesi before the establishment of Bunaken National Marine Park in 1991 (Lane and Limbong, 2013).
There is now worldwide interest in sea cucumber aquaculture. For example, Japan reported being the first country to successfully culture sea cucumber Apostichopus japonicas (Vanuccini, 2004). Aquaculture production of sea cucumbers has occurred in countries such as Australia, Maldives, Solomon Islands, India, and Indonesia (Pangkey et al., 2012). In North Lombok, Indonesia, about 6,000 offspring were produced annually from wild broodstock reared and spawned in land-based aquaculture facilities (Indriana, pers. comm.).

Several techniques had been established in an attempt to increase the hatchery-produced juveniles of sea cucumbers (Battaglene, 1999; Pitt, 2001; Agudo, 2006). For example, newly settled juveniles are reared in the sand and staked plate in rearing tanks (Battaglene, 1999; Pitt, 2001). However, production cost, nursery technology, and survival rate of the cultured juvenile are still a challenge (Purcell, 2004; Bell et al., 2007; Purcell and Simutoga, 2008).

To achieve commercial size, sea cucumbers are commonly grown in various grow-out systems such as in seawater ponds (Duy, 2012), the sea (Robinson and Pascal, 2012; Junio-Menez et al., 2013) and land-based system applying a 
recirculating water system (Robinson, 2013). Sea ranching of $H$. scabra, however, still faces some technical and social constraints (Mills et al., 2012; Purcell et al., 2012).

Low survival of juvenile $H$. scabra released after hatchery stage has been reported in some countries: $20-30 \%$ in sea ranches in the Philippines (Junio-Menez et al., 2012; JunioMenez et al., 2013), 20-40\% in sea pens in Fiji (Hair et al., 2011), 14\% in northern Australia (Hair et al., 2016) and less than 15\% in Maldives (James, 2012). The high mortality of juvenile $H$. scabra released to the sea following the hatchery stages was related mainly to predation, transport stress, washed away by a strong current and extreme weather (Purcell, 2004; Robinson and Pascal, 2012).

Sea cucumber H. scabra grow-out at sea have been conducted in some areas in Indonesia such as in Bengkulu, Kepulauan Seribu, and Tual in Southeast Maluku (Hartati, 2008). However, a similar effort has not been reported in North Sulawesi. The assessment of site suitability for sea cucumber $H$. scabra is a preliminary study for a long-term community-based sea cucumber ranching program in North Sulawesi. As local exploitation of sea cucumber in some areas has recently shifted to low commercial value species (Supono, unpublished data), it suggests that populations of high commercial values may have been depleted. Developing sea cucumber fishing ground into the grow-out site has the potential to replenish natural populations. Therefore, establishing a comprehensive analysis of site development for $H$. scabra could increase the success rate of a sea ranching program. This study aims to determine the suitable coastal areas in North Sulawesi to be further developed as sea cucumber H. scabra grow-out sites.

\section{MATERIALS AND METHODS}

Multi-criteria decision-making tool, Analytical Hierarchy Process (AHP) (Saaty, 2008) was applied to analyze site suitability ranking among the three locations. The goal of the AHP in this study was to determine the suitability of H. scabra grow-out location, and the priority of each location to be utilized as a grow-out site. (Figure 2). Each criterion was compared pairwise to each other, forming matrices of each level of criteria. Numeric scale, from 1 to 9 , was used to represent the intensity of significance of comparing criterion, where the lowest number (1) implies that two criteria are equally important, and the highest number (9) implies that one criterion is extremely more important than another. The priority for each criterion was obtained by calculating the sum of each row of the matrix and dividing by the total sum of the matrix.

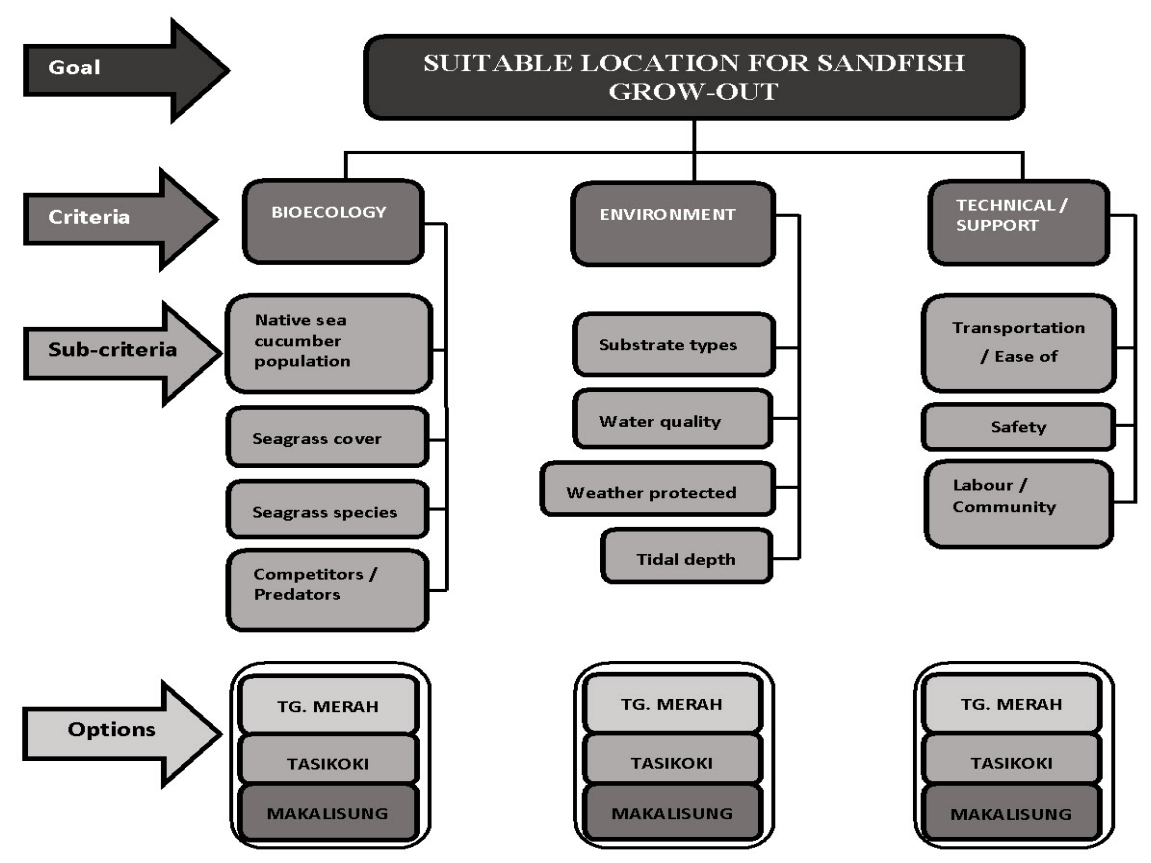

Figure 2. The Analytical Hierarchy Process (AHP). 


\section{Main Criteria}

Main criteria were established based on the general requirements for sea cucumber grow-out site as highlighted in the works of Agudo (2006), Giraspy and Walsalam (2010), Pascal et al. (2011), and Purcell (2012). They were three main criteria: bioecology, environment, and technical/ support. Each criterion was then compared pairwise to determine their significance towards the goal of achieving the suitable site for $H$. scabra grow-out.

\section{Sub-Criteria}

Each criterion above was broken down to several sub-criteria. On the hierarchical setting of the AHP, these sub-criteria were compared pairwise to each other. The formulation of each sub-criterion was based on established guidelines for sea cucumber grow-out by Agudo (2006), Giraspy and Walsalam (2010), and Pascal et al. (2011). For environmental and technical/ support criteria, the general assumption of best management practice for responsible aquaculture (Boyd et al., 2008) was used where applicable. Bioecology was broken down to three sub-criteria, which are native sea cucumber population, seagrass bed population, and competitor/ predator. Sub-criteria for environment included the type of substrates, water quality, protection from the weather, and tidal depth. Moreover, the technical/support criteria had three sub-criteria, i.e., transportation (ease of access), safety (risk and hazard assessment), and community/labor support.

\section{Options/Locations}

The next step for the AHP was to compare each sub-criterion with an option, in this case, an alternative location for sea cucumber growout site. Three coastal areas of North Sulawesi (Tanjung Merah, Tasikoki, and Makalisung) were designated as potential sites for aquaculture site development (Figure 1). Tanjung Merah and Tasikoki are traditional fishing villages within 5 $\mathrm{km}$ of a distance of each other, while Makalisung is a fishing village approximately $15 \mathrm{~km}$ southeast of Tasikoki with white sand beaches primarily used for tourism. In terms of sea cucumber fisheries, all locations have seagrass beds with various mixtures of sand, mud and rubbles substrate, which are potential habitats for many commercial sea cucumbers including $H$. scabra. However, fishers specialized in collecting sea cucumbers are only found in Tasikoki, despite their fishing ground that stretches to the seagrass beds along the coast of the Molucca Sea.

Sampling sites consisted of two sites in Tanjung Merah, two sites in Tasikoki and five sites in Makalisung, with a distance between sites were about $0.5-1 \mathrm{~km}$. The bioecological and environmental assessment was mostly conducted on each site, while all technical and support assessment were conducted per location area (Table 1). Sets of criteria, sub-criteria, and options were placed into a hierarchical chart to show the complete analytical framework (Figure 2).

Table 1. Sub-criteria assessment conducted on options/locations.

\begin{tabular}{|c|c|c|c|}
\hline Assessment & Methods & Analysis & Scope \\
\hline Seagrass ecology & Line transect & species numbers and dominance, seagrass covers, & Per site \\
\hline H. scabra ecology & Belt transect & Community structures & Per site \\
\hline Predators/Competitors & Belt transect/Visual & Species numbers, Ecological roles & Per site \\
\hline Substrate & Visual & Substrate type & Per site \\
\hline Water quality & $\begin{array}{l}\text { On site measurement: } \\
\text { Temperature, salinity, } \mathrm{pH}, \mathrm{DO}\end{array}$ & Suitability to $H$. scabra livelihood & Per site \\
\hline Tidal depth & Visual & Seasonal high and low tide & Per location \\
\hline Transportation & Field survey & Distance and type of roads & Per location \\
\hline Safety & Field survey, interviews & Risk assessment & Per location \\
\hline Labor/Community supports & Field survey, interviews & Socio-economic assessment & Per location \\
\hline
\end{tabular}




\section{RESULTS}

Pairwise matrix comparison using the AHP analysis of criteria and sub-criteria used in this study demonstrates that Tasikoki has the optimum suitability to be developed as a sea cucumber H. scabra grow-out site. Out of the eleven subcriteria assessed in three locations, seven subcriteria observed in Tasikoki demonstrate higher values. Matrix scoring between each criterion for site suitability analysis for Holothuria scabra juvenile and grow-out is shown in Table 2. Matrix scoring between sub-criteria (bioecology, environment, and technical/support) are shown in Table 3.

For the bioecology parameters, Tasikoki demonstrates high suitability based on natural sea cucumber population and seagrass species composition (60.54 and $64.13 \%$, respectively). In contrast, Makalisung demonstrates the lowest suitability compared to the other two sites, although it has the lowest presence of competitors or predators (Figure 3-top).

For environmental parameters, Tasikoki demonstrates the highest suitability for bottom substrate, site protection from rough weather and wave, and water depth during the lowest tides (57.53, 69.20 and $64.13 \%$, respectively). Similar to the bioecology parameters, Makalisung demonstrates the lowest suitability (Figure 3-middle).

The highest suitability in the technical/ support sub-criteria is also demonstrated in Tasikoki, where two sub-criteria (safety and labor/community) show the highest percentages among the three sites (47.68 and 64.13\%, respectively). However, Tasikoki demonstrates the lowest percentage of access to only $8.81 \%$ (Figure 3-bottom).

Table 2. Matrix scoring between each criterion for site suitability analysis for Holothuria scabra juvenile and grow-out.

\begin{tabular}{|l|c|c|c|c|}
\hline & BIOECOLOGY & ENVIRONMENT & $\begin{array}{c}\text { TECHNICAL/ } \\
\text { SUPPORT }\end{array}$ & PRIORITY \\
\hline BIOECOLOGY & & 0.33 & 0.5 & 0.162 \\
\hline ENVIRONMENT & 3 & & 2 & 0.529 \\
\hline TECHNICAL/SUPPORT & 2 & 0.5 & & 0.309 \\
\hline
\end{tabular}

Table 3. Matrix scoring between sub-criteria of bioecology, environment, and technical/support.

\begin{tabular}{|c|c|c|c|c|c|}
\hline BIOECOLOGY & $\begin{array}{c}\text { Native sea } \\
\text { cucumber pop. }\end{array}$ & $\begin{array}{c}\text { Seagrass } \\
\text { cover }\end{array}$ & $\begin{array}{l}\text { Seagrass } \\
\text { species }\end{array}$ & $\begin{array}{l}\text { Comps/ } \\
\text { Preds }\end{array}$ & PRIORITY \\
\hline Native sea cucumber pop. & 1 & 0.2 & 0.33 & 0.33 & 0.079 \\
\hline Seagrass cover & 5 & 1 & 0.5 & 0.5 & 0.299 \\
\hline Seagrass species & 3 & 2 & 1 & 0.5 & 0.278 \\
\hline Comps/Preds & 3 & 2 & 2 & 1 & 0.342 \\
\hline ENVIRONMENT & Substrate & $\begin{array}{l}\text { Water } \\
\text { quality }\end{array}$ & Weather protected & $\begin{array}{r}\text { Tidal } \\
\text { depth }\end{array}$ & PRIORITY \\
\hline Substrate & 1 & 3 & 5 & 1 & 0.420 \\
\hline Water quality & 0.33 & 1 & 4 & 0.5 & 0.245 \\
\hline Weather protected & 0.2 & 0.25 & 1 & 0.5 & 0.082 \\
\hline Tidal depth & 1 & 2 & 2 & 1 & 0.252 \\
\hline TECHNICAL/SUPPORT & Transportation & \multicolumn{2}{|c|}{ Safety } & $\begin{array}{l}\text { Labor/ } \\
\text { Community }\end{array}$ & PRIORITY \\
\hline Transportation & 1 & \multicolumn{2}{|c|}{0.2} & 0.33 & 0.103 \\
\hline Safety & 5 & \multicolumn{2}{|c|}{1} & 3 & 0.605 \\
\hline Labor/Community & 3 & \multicolumn{2}{|c|}{0.33} & & 0.291 \\
\hline
\end{tabular}




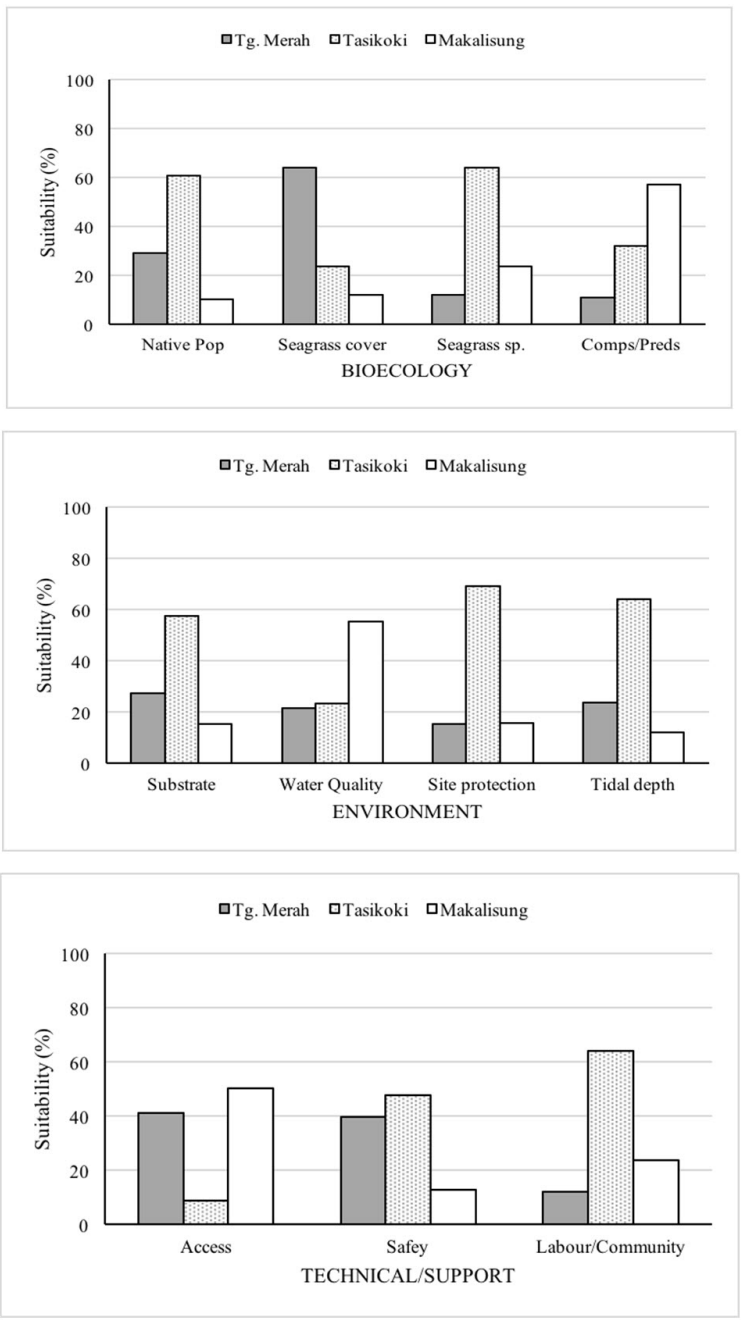

Figure 3. Site suitability of three locations based on (top) bioecology, (middle) environmental conditions, and (bottom) technical/support.

\section{DISCUSSION}

In our study, Tasikoki shows the highest suitability among other sites and the lowest limiting factors for the success of $H$. scabra sea ranching. Limiting factors in sea cucumber ranching may include biological, technical, and social constraints (Eriksson et al., 2012). It has been shown that stress during transportation, strong current, extreme weather, and the presence of predators adversely affect the survival of sea cucumber juveniles (Purcell, 2004; Robinson and Pascal, 2012).

Bioecologically, Tasikokirepresents the highest suitability of seagrass species composition with a high density of Enhalus acoroides, Thalassia hemprichii and native sea cucumber population, particularly H. scabra. H. scabra is most abundant in Tasikoki compared to the two other sites. Site suitability analysis using principal component analysis demonstrates that higher survival of $H$. scabra in sites with high seagrass cover, high chlorophyll-a, epiphyte growth on seagrass leaves (Hair et al., 2016). While seagrass species composition is a crucial aspect, particularly for larval settlement of $H$. scabra at hatchery stages (Mercier et al., 2000), seagrass is also beneficial for a later stage. H. scabra at about $10 \mathrm{~mm}$ in body length or $1 \mathrm{~g}$ in weight are commonly found migrating from dense seagrass to nearby mud-sand substrata (Mercier et al., 2000). At this stage, seagrass canopy provides protection, while seagrass leaves trap more nutrients particularly at the baseline that is beneficial to deposit feeders including some deposit-feeding sea cucumbers (Moriarty, 1982; Komatsu et al., 2004).

The high presence of native sea cucumber population in Tasikoki compared to the other two locations in this study may be correlated with environmental parameters particularly substrate, site protection from rough weather and waves, and a minimum of $50 \mathrm{~cm}$ water depth during low tide. Bottom substrate composition in Tasikoki is composed of a mixture of sand and mud that appears preferable for living habitat of $\mathrm{H}$. scabra. This substratum preference is similar to the work of Altamirano et al. (2017) who reported that sandy mud sediment increases burying and feeding, while silty mud sediment is unsuitable for $H$. scabra grow-out. Furthermore, Tasikoki has the most protected sites from wave and strong current as it has a natural sand embankment buffer. In contrast, Tanjung Merah and Makalisung are heavily affected by strong annual monsoon waves. Indeed, the strong current is a major cause of low survival, causing large numbers of the released juvenile being washed away (Purcell, 2004; Robinson and Pascal, 2012).

In terms of technical support, Tasikoki scores lowest for land transportation access. The entrance access from the main road to the coastal area is mainly unsealed gravel road thus may increase transportation stress on sea cucumber juveniles. However, it may be resolved by two options, which are transportation by boat and utilizing short term cage protection on relocation sites. Hair et al. (2016) suggested that the use of 
cage does not perform better in terms of juvenile's survival compared to the free release system, but short term cage protection may be essential to acclimatize released juveniles from transport stress, as well as minimize extended stress and vulnerability to predators. Another option is to release larger sized juveniles to increase their tolerance to transport and handling stress. It has been reported that mortality of released juveniles is inversely related to juvenile size, in which the highest mortality occurs for small juveniles (Dance et al., 2003; Purcell and Simutoga, 2008).

Another major factor causing poor survival of juvenile H. scabra in sea-based grow-out is predation. Fish, gastropods, crustaceans, and sea stars are common predators of holothurian (Knopp, 1982; Francour, 1997; Zamora and Jeffs, 2013). Predation by fish and crustaceans had been frequently recorded in sea cucumber aquaculture (Hair et al., 2016). The presence of predators in Tasikoki site is moderate (second rank among locations). Juveniles' vulnerability to predation can be reduced to increase the site suitability of Tasikoki by applying methods suggested by Hair et al. (2016): maximizing the size of released juvenile, manually removing predator, and installing protection from a predator such us closed sea pens. In contrast, Lavitra et al. (2015) reported that the use of nursery-reared juveniles and the size of juvenile $H$. scabra do not significantly increase the survival rate after they are released in farming sites. However, this only applies to sites where the presence of predators is low.

\section{CONCLUSION}

Our study suggests that Tasikoki is a potential grow-out site for hatchery-reared $H$. scabra. Tasikoki has bioecological, environmental and technical/support features that are crucial for living habitat of juvenile $H$. scabra. The limitation of some criteria in Tasikoki could be resolved by applying biological and technical techniques to maximize site suitability. Further researches could include analysis on key sediment parameters and conduct a grow-out trial of hatchery-reared juvenile $H$. scabra in Tasikoki to investigate the growth and survival of juveniles.
In fisheries management principles and approach for sea cucumber, managing fishing activities has emerged since depletion of natural stock occurs globally (Purcell et al., 2013). One of the common recent efforts is to breed captive adult sea cucumbers and to release hatcheryreared juveniles either in sea pens farming or natural habitat sea ranching involving the local community as part of the project (Bell et al., 2008; Hair et al., 2016). Low technology sea cucumber ranching applying traditional method 'put,' grow and harvest' in the marine environment was suggested to hold potential as a sustainable livelihood as well as sea cucumber production (Hair et al., 2016).

\section{ACKNOWLEDGEMENT}

This study was funded by LKBL LIPI Bitung's DIPA. We thank technicians of the LKBL LIPI Bitung for their assistance. Both authors contributed equally in preparing the content of this paper including designing experiment, analysing data, writing and revising manuscript

\section{REFERENCES}

Agudo, N. (2006). Sandfish Hatchery Techniques. Australian Centre for International Agricultural Research (ACIAR), Secretariat for the Pacific Community (SPC), WorldFish Center. (pp. 43).

Altamirano, J. P., Recente, C. P. and Rodriguez, Jr., J. C. (2017). Substrate preference for burying and feeding of sandfish Holothuria scabra juveniles. Fish. Res., 186, 514-523. doi:10.1016/j.fishres.2016.08.011.

Battaglene, S. C. (1999). Culture of tropical sea cucumbers for stock restoration and enhancement. Naga, The ICLARM Quarterly, 22(4), 4-11.

Bell, J. D., Leber, K. M., Blankenship, H. L., Loneragan, M. R. and Masuda, R. (2008). A new era for restocking, stock enhancement and sea ranching for coastal fisheries resource. Rev. Fish. Sci., 16(1-3), 1-9. doi:10.1080/10641260701776951.

Boyd, C. E., Lim, C., Queiroz, J., Salie, K., 
de Wet, L. and McNevin, A. (2008). Best management practices for responsible aquaculture. USAID. (pp. 47).

Dance, S. K., Lane, I. and Bell, J. D. (2003). Variation in short-term survival of cultured sandfish (Holothuria scabra) released in mangrove-seagrass and coral reef habitats in Solomon Islands. Aquacult., 220, 495-505. doi:10.1016/S0044-8486(02)00623-3.

DGA (Directorate General of Aquaculture). (2015). Strategic plan of Directorate General of Aquaculture, Indonesia 2015-2019. Directorate General of Aquaculture, (pp. 38).

DGCF (Directorate General of Capture Fisheries). (2015). Statistics of marine capture fisheries by fisheries management area (FMA), 2005-2014. Directorate General of Capture Fisheries, Indonesia. (pp. 486).

Duy, N. D. Q. (2012). Large-scale sandfish production from pond culture in Vietnam. In Hair, C. A., Pickering, T. D. and Mills, D. J. (eds), Asia-Pacific Tropical Sea Cucumber Aquaculture. Australian Center for International Agriculture Research, Canberra. ACIAR Proceeding, 136, 34-39.

Eriksson, H., Robinson, G., Slater, M. and Troell, M. (2012) Sea cucumber aquaculture in the western Indian Ocean: challenges for sustainable livelihood and stock improvement. AMBIO: A Journal of the Human Environment, 41(2), 109121. doi:10.1007/s13280-011-0195-8.

Francour, P. (1997). Predation on holothurians: a literature review. Invertebr. Biol., 116(1), 5260. doi:10.2307/3226924.

Giraspy, D. A. B. and Walsalam, I. G. (2010). Aquaculture potential of the tropical sea cucumbers Holothuria scabra and $H$. lessoni in the Indo-Pacific region. SPC Bechede-mer Information Bulletin, 30, 29-32.

Hair, C., Foale, S., Kinch, J., Yaman, L. and Shouthgate, P. (2016). Beyond boom, bust and ban: the sandfish (Holothuria scabra) fishery in the Tigak Islands, Papua New Guinea. Reg. Stud. Mar. Sci., 5, 69-79. doi:10.1016/j. rsma.2016.02.001.

Hair, C., Mills, D. J., McIntyre, R. and Southgate, P. C. (2016). Optimising methods for community-based sea cucumber ranching: experimental releases of cultured juvenile Holothuria scabra into seagrass meadows in Papua New Guinea. Aquacult. Rep., 3, 198-208. doi: 10.1016/j. aqrep.2016.03.004.

Hair, C., Pickering, T., Semisi, M., Vereivalu, T., Hunter, J. and Cavakiqali, L. (2011). Sandfish culture in Fiji Islands. SPC-Beche-de-mer Information Bulletin, 31, 3-11.

Hartati, S. T. (2008). Pengkayaan stok teripang pasir (Holothuria scabra) di perairan Kepulauan Seribu. Bawal, 2(1), 9-15. doi:10.15578/bawal.2.1.2008.9-15.

James, C. M. (2012). Sea cucumber in the Maldives. Aquaculture Asia Pacific Magazine Sept-Oct, 43-44.

Junio-Meñez, M. A., Dumalan, R. J. P., Edullantes, C. M. and Catbagan, T. O. (2012). Ocean nursery systems for scaling up juvenile sandfish (Holothuria scabra) production: ensuring opportunities for small fishers. In Hair, C. A., Pickering, T. D. and Mills, D. J. (eds), Asia-Pacific Tropical Sea Cucumber Aquaculture. Australian Center for International Agriculture Research, Canberra. ACIAR Proceeding, 136, 57-62.

Junio-Meñez, M. A., Evangelio, J. C., Olavides, R. D., Catbagan, T. O., Edullantes, C. M. A., Rodriguez, B. D. R. and Casilagan, I. L. N. (2013). Population dynamics of cultured Holothuria scabra in a sea ranch: implications for stock restoration. Rev. Fish. Sci., 21(3-4), 424432. doi:10.1080/10641262.2013.837282.

Knopp, R. K. (1982). Responses of five holothurian species to attacks by a predatory gastropod, Tonna perdix. Pac. Sci., 36(4), 445-452. 
Komatsu, T., Umezawa, Y., Nakakoka, M., Supanwand, C. and Kanamoto, Z. (2004). Water flow and sediment in Enhalus acoroides and other seagrass beds in the Andaman Sea, Off Khao Bae Na, Thailand. Coast. Mar. Sci., 29(1), 63-68.

Lane, D. J. W. (1999). A population survey of the 'rare' stichopodid sea cucumber, Thelenota rubralineata, of northern Sulawesi, Indonesia. In Carnevali, M. D. C. and Bonasoro, F. (eds). Echinoderm research. Proceeding the 5th European Conference on Echinoderms, Milan. AA Balkema: Rotterdam. (pp. 499503).

Lane, D. J. W. and Limbong, D. (2013). Catastrophic depletion of reef-associated sea cucumber: resource management/reef resilience issues for an Indonesian marine park and the wider Indo-Pacific. Aquat. Conserv., 25(4), 505-517. doi:10.1002/aqc.2421.

Lavitra, T., Tsiresy, G., Rasolofonirina, R. and Eeckhaut, I. (2015). Effects of nurseries and size of released Holothuria scabra juveniles on their survival and growth. SPC Beche-demer Information Bulletin, 35, 37-41.

Máñez, K. L. and Ferse, S. C. A. (2010). The history of Makassan trepang fishing and trade. PLoS One, 5(6), 1-8. doi:10.1371/ journal.pone.0011346.

Mercier, A., Battaglene, S. C. and Hamel, J-F. (2000). Settlement preferences and early migration of the tropical sea cucumber Holothuria scabra. J. Exp. Mar. Biol. Ecol., 249, 89-110. doi:10.1016/S00220981(00)00187-8.

Mills, D. J., Duy, N. D. Q., Junio-Menez, M. A., Raison, C. M. and Zarate, J. M. (2012). Overview of sea cucumber aquaculture and sea-ranching research in South-East Asian region. In Hair, C. A., Pickering, T. D. and Mills, D. J. (eds). Asia-Pacific Tropical Sea Cucumber Aquaculture. Australian Center for International Agriculture Research, Canberra. ACIAR Proceeding, 136, 22-31.
Moriarty, D. (1982). Feeding of Holothuria atra and Stichopus chloronatus on bacteria, organic carbon and organic nitrogen in sediments of the Great Barrier Reef. Aust. J. Mar. Freshwater Res., 33(2), 255-263. doi:10.1071/MF9820255.

Pangkey, H., Lantu, S., Manuand, L. and Mokolensang, J. F. (2012). Prospect of sea cucumber culture in Indonesia as potential food sources. J. Coast. Dev., 15(2), 114-124.

Pascal, B., Robinson, G., De San, M. and Rajaonarison, P, 2010. Handbook for sandfish farming. Regional Programme for the Sustainable Management of the Coastal Zones of the Countries of the Indian Ocean (ReCoMaP). (pp. 66).

Pitt, R. 2001. Review of sandfish breeding and rearing methods. SPC Beche-de-mer Information Bulletin, 14. 4-21.

Purcell, S. W. (2004). Criteria for release strategies and evaluating the restocking of sea cucumbers. In Lovateli, A., Condan, C., Purcell, S. Uthicke, S., Hamel, J. F. and Mercier, A. (eds). Advances in sea cucumber aquaculture and management. FAO Fisheries technical paper no 463 FAO, Rome. (pp. 181191).

Purcell, S. W. and Situmoga, M. (2008). Spatiotemporal and size-dependent variation in the success of releasing cultured sea cucumbers in the wild. Rev. Fish. Sci., 16(1-3), 204-214. doi: 10.1080/10641260701686895.

Purcell, S. W., Hair, C. A. and Will, D. J. (2012). Sea cucumber culture, farming and sea ranching in the tropics: progress, problems and opportunities. Aquacult., 368-369, 6881. doi:10.1016/j.aquaculture.2012.08.053.

Purcell, S. W., Mercier, A., Conand, C., Hamel, J-F., Toral-Granda, M. V., Lovatelli, A. and Uthicke, S. (2013). Sea cucumber fisheries: global analysis of stocks, management measures and drivers of overfishing. Fish Fish., 14, 34-59. doi: 10.1111/j.14672979.2011.00443.x. 
Robinson, G. (2013). A bright future for sandfish. World Aquacult., 44(1), 19-24.

Robinson, G. and Pascal, B. (2012). Sea cucumber farming experiences in south-western Madagascar. In Hair, C. A., Pickering, T. D. and Mills, D. J. (eds). Asia-Pacific Tropical Sea Cucumber Aquaculture. Australian Center for International Agriculture Research, Canberra. ACIAR Proceeding, 136, 142-155.

Saaty, T. L. (2008). Decision making with the analytic hierarchy process. International Journal of Service Sciences, 1(1), 83-98. doi: 10.1504/IJSSci.2008.01759.
Vannuccini, S. (2004). Sea cucumbers: a compendium of fishery statistics. Workshop on advances in sea cucumber aquaculture and management (ASCAM), Dalian, Liaoning Province, China. Food and Agriculture Organization, Rome, Italy.

Zamora, L. N. and Jeffs, A. G. (2013). A review of the research on the Australasian sea cucumber, Australostichopus mollis(Echinodermata:holothuroidea)(Hutton 1872), with emphasis on aquaculture. Journal of Shellfish Research, 32(1), 613-627. doi: 10.2983/035.032.0301. 